\title{
Psikolojik Danışman Adaylarının Psikolojik Danışma Becerileri ve Özyeterliklerine iliş̧kin Görüşleri
}

\section{Opinions of Counselor Candidates on Counseling Skills and Self-Efficacy}

\author{
Büşra EMÜL , Uzman Psikolojik Danışman, Marmara Üniversitesi, Eğitim Bilimleri Enstitüsü, busraemull@gmail.com
}

Fatma Selda ÖZ SOYSAL , Doç. Dr., Dokuz Eylül Üniversitesi, Eğitim Bilimleri Enstitüsü, seldaoz.oz@gmail.com

Emül, B. ve Öz Soysal F. S. (2021). Psikolojik Danışman Adaylarının Psikolojik Danışma Becerileri ve Özyeterliklerine İlişkin Görüşleri. Batı Anadolu Eğitim Bilimleri Dergisi, 12(2), 500-514.

Öz. Bu araştırmanın amacı psikolojik danışman adaylarının psikolojik danışma becerileri ve psikolojik danışman özyeterliğine yönelik algılarının ortaya koymaktır. Çalışma grubu, uygun örnekleme yöntemi ile seçilen Rehberlik ve Psikolojik Danışmanlık bölümü 129 4.sınıf lisans öğrencisinden oluşmaktadır. Araştırmanın amacı doğrultusunda psikolojik danışman adaylarının etkili kullandıkları, kullanmakta güçlük çektikleri ve geliştirmek istedikleri psikolojik danışma becerileri ile etkili çalışabildikleri ve çalışmakta güçlük çektikleri danışanlara ilişkin görüşleri belirlenmeye çalışılmıştır. Durum çalışmasının kullanıldığı bu nitel araştırmada yarı yapılandırılmış görüşme formu kullanılmış ve elde edilen veriler içerik analizi yöntemi ile çözümlenmiştir. Elde edilen bulgular sonucunda Psikolojik danışman adaylarının mikro yardım becerilerinden etkili kullandıkları, güçlük yaşadıkları ve geliştirmek istedikleri psikolojik danışma becerilerinin içerik ve duygu yansıtma becerileri etrafında toplandığı belirlenmiştir. Psikolojik danışman adaylarının psikolojik danışma süreci boyunca güçlük yaşadığı konular ve danışan özelliklerine yönelik algıları konusunda dışadönük/kendini açan/ konuşkan danışanlar ile daha etkili çalışabildikleri görülmüştür. Psikolojik danışman adaylarının psikolojik danışma süreci boyunca güçlük yaşadığı konular ve danışan özelliklerine yönelik algıları konusunda içedönük/konuşmayan/ kendini açmayan danışanlar ile çalışmakta zorlandıkları sonucuna ulaşılmıştır.

Anahtar Kelimeler: Psikolojik danışma, Psikolojik danışman adayı, Psikolojik danışma becerileri, Özyeterlik.

\begin{abstract}
The aim of this study is to reveal the perceptions of counseling candidates towards counseling skills and counseling self-efficacy. The study group consists of 129 4th grade undergraduate students from the Department of Counseling and Guidance, selected with the appropriate sampling method. In line with the purpose of the study, it was tried to determine the opinions of the psychological counselor candidates about the counselors whom they had difficulty in using, and could work effectively with the counseling skills they wanted to improve. In this qualitative study in which case study was used, semi-structured interview form was used and the obtained content was analyzed with the method of content analysis. As a result of the findings, it was determined that the counseling skills that the counselor candidates used effectively, had difficulties and wanted to improve were gathered around their content and emotion reflection skills. It has been observed that counselor candidates can work more effectively with extroverted/self-disclosed/talkative clients on the issues they have difficulty with and their perceptions of client characteristics during the counseling process. It has been concluded that counselor candidates have difficulties in working with introverted/non-speaking/nonself-disclosed clients regarding the issues they have difficulty with and their perceptions of client characteristics during the counseling process.
\end{abstract}

Keywords: Counseling, Counseling candidates, Counseling skills, Self efficacy. 


\section{Extended Abstract}

Introduction. Basic counseling skills; focusing / paying attention, minimal encouragement, effective questioning, observation, summarizing, reflection of content and emotion. Advanced counseling skills, on the other hand; self-disclosure, engagement, transparency, personalization of meaning, problem and purpose, empathy, confrontation skills. Psychological counselors need self-efficacy in order to use all these skills effectively. Psychological counselor self-efficacy is the belief that the psychological counselor is competent to successfully use and apply the skills he / she has (Bakioğlu, 2017). Beliefs about what psychological counselors can do is an important component in the healthy and successful operation of the psychological counseling process (Asarl, 2012). It has been observed that psychological counselors with high levels of self-efficacy experience less stress in counseling, are more willing to get to know clients, and are more ready to apply counseling skills (Lannin, Gyull, Cornish, Vogel, \& Madon, 2018). The aim of this study is to reveal the perceptions of counseling candidates towards counseling skills and counseling self-efficacy.

Method. The study was carried out in accordance with the case study model, which is one of the qualitative research methods in line with the purpose of the study. The study group of the study was selected with the appropriate sampling method, 93 (72.1\%) women and $36(27.9 \%)$ men who were studying in the Department of Counseling and Guidance in İzmir, Manisa, Düzce, Sakarya and Aydın provinces in the 2020-2021 academic year. It consists of 129 senior psychological counselor candidates. In the research, semi-structured interview form was applied as a data collection tool. This form consists of 5 open-ended questions. Content analysis method was used in analyzing the data. After the data were examined, it was determined under which subject headings they were collected, and then the analysis process was completed and sub-themes and codes were created.

Results. The answers given to the question asked were evaluated in order to determine the perceptions of the counselor candidates about using micro-assistance skills effectively. According to the data obtained from the first question, the micro skills they used effectively were determined as the main theme. According to the data obtained from the second question, the micro skills they had difficulty using were determined as the main theme. Based on the data obtained from the third question, the micro skills they wanted to develop were determined. Three sub-themes were determined according to the data obtained from the fourth question. These themes are; the personality traits of the clients, the problems they experience and the developmental period of the clients. Three sub-themes were determined according to the data obtained from the fifth question. These themes are; the personality traits of the clients, the problems they experience and the developmental period of the clients.

Discussion and Conclusion. The data obtained from the first question of the study are in line with the conclusion that Atıcı and Ulusoy (2010) used their skills of reflection, encouragement, listening, selfdisclosure, confrontation and asking questions. At the same time, the counselors of Şahin, Togay and Atıl (2009), who achieved similar results, frequently; It supports the conclusion that they use the skills of reflecting content and emotion, encouragement, structuring, minimum level of encouragement, confrontation and self-disclosure. When the findings obtained from the second question of the interview are examined, the skills of reflecting emotion, reflecting content, asking questions, summarizing, focusing / paying attention, minimal encouragement, listening, open invitation to speak, confrontation, silence, interpretation, self-disclosure, personalization, transparency and giving feedback. It was concluded that they had difficulty using them. Aladağ, Yaka and Koç (2014), in their study, found that the basic skills that counselor candidates find most difficult are; verbal follow-up, asking questions, and reflecting emotions. Reflection skills from the skills that counselors have difficulty using is an important element of effective therapeutic relationships and 
communication, which can be considered as the basis of many counseling skills (Meydan, 2015). When the findings obtained from the third question of the interview are examined, the skills of reflecting emotion, reflecting content, asking questions, summarizing, focusing / paying attention, open invitation to speak, minimal encouragement, listening, confrontation, interpretation, silence, self-disclosure, empathy, personalization, transparency, and binding It was concluded that they wanted to improve. Examining the findings obtained from the fourth question of the interview, the client's personality traits include extroverted /self disclousure / talkative, willing and cooperative, amenable, harmonious and calm, pessimistic, determined, emotional, introverted, rational clients), level of self-expression and awareness level. It was concluded that they work effectively with clients who have positive self-perception, those who come from a neurotic, cultural background similar to counselors, and those who do not show resistance and have responsibility. Another issue that counselor candidates work effectively has been evaluated within the scope of the problem area. When the findings obtained from the fifth question of the interview were examined, within the scope of the client's personality traits, those who were introverted / non-speaking / unwilling to change, unwilling to change, rebellious, questioning, stubborn, different world views, irresponsible, manipulative, talkative, contradictory, emotional / melancholic, careless, impatient, low awareness. It was concluded that the clients were fixed minded, incongruent / rude, perfectionist, unaware of their feelings, angry, pessimistic and complaining. Another issue that counselor candidates have difficulty in working has been evaluated within the scope of the problem area. Counselor candidates have anxiety problems, the client who is abused or abused, the client who is prone to suicide, abuse / harassment / murder crime, depressed, mourning counseling, psychotic, violent client, clients with self-esteem, violent client, intensive support It was concluded that clients with needy clients, complex problems, romantic relationships, cognitive and spiritual problems, counselors have difficulties to cope with, obsessive, social phobia, angry, stuck with the past, and low self-esteem. Another area of evaluation is the development period of the client. It was concluded that counselors had difficulty working with clients in adulthood, childhood, old age, and adolescence. In this context, it may be suggested that counselors / prospective counselors receive ethical training, learn about dangerous clients and their characteristics, and improve their decision-making and coping skills (ikiz, 2017). 


\section{Giriş}

Amerikan Psikolojik Danışma Derneği (ACA), profesyonel psikolojik danışmanlığı "Bireyin patolojisinin yanı sıra, iyilik hali, kişisel veya mesleki gelişim becerileri olan stratejiler, bilişsel, duyuşsal, davranışsal ya da sistematik müdahaleler ile ruh sağlığı, psikoloji ya da insani gelişim esaslarının uygulanmasıdır" şeklinde ifade etmektedir (Hackney ve Comier, 2008). Bu kapsamda psikolojik danışman, ruh sağlığı ilkeleri, psikolojik danışma becerileri ve etik ilkeleri kendi kişiliği ile bütünleştirerek psikolojik danışmayı gerçekleştiren ve psikolojik yardımı sunan meslek uzmanı olarak tanımlanabilir. Bir meslek uzmanı olarak psikolojik danışmanlar Türkiye'de lisans eğitimi kapsamında psikolojik danışma uygulaması aşamasına gelmeden önce birçok teorik ve uygulamalı eğitimden geçmektedirler. Bu eğitimlerde, psikolojik danışman adaylarına psikolojik danışma kuramları, psikolojik danışma beceri ve teknikleri, iletişim becerileri, bireyle psikolojik danışma, grupla psikolojik danışma gibi teorik ve uygulama dersleri yoluyla psikolojik danışma yapabilmeleri için gerekli olan yeterliklerin ve becerilerin kazandırılması amaçlanmaktadır.

Psikolojik danışma becerisi, psikolojik danışmaya gelen danışanın kendini ifade etmesine yardımcı olarak, danışanın problemine farklı bir yaklaşım sergilemesi ve çözüm için gerekli adımları atabilmesi adına psikolojik danışman tarafından gerekli yöntem, teknik ve basamakların uygulanmasıdır (Uslu, 2005). Diğer bir tanıma göre psikolojik danışma becerileri, psikolojik danışmanda olması gereken tüm becerileri kendine dâhil etmekle birlikte danışan- psikolojik danışman ilişkisinde amaca yönelik temel, ileri düzey ve terapötik becerileri kapsamaktadır (Yaka, 2005). Temel psikolojik danışma becerileri; odaklanma/ dikkati verme, asgari düzeyde teşvik, etkili soru sorma, gözlem, özetleme, içerik ve duygu yansıtmadır. İleri düzey psikolojik danışma becerileri ise; kendini açma, bağlama, saydamlık, anlamın, problemin ve amacın kişiselleştirilmesi, empati, yüzleştirme becerilerini kapsamaktadır (Voltan-Acar, 2015). Temel psikolojik danışma becerileri aynı zamanda mikro yardım becerileri olarak da alan yazında yer almaktadır. Psikolojik danışmanların tüm bu becerileri etkili olarak kullanabilmesi için de özyeterliğe ihtiyacı bulunacağı söylenebilir.

Özyeterlik, temeli Albert Bandura'nın sosyal bilişsel kuramına dayanan bir kavramdır. Bireyin kendini değerlendirip bir işi yapabileceğine yönelik inancı olarak tanımlanır (Bandura, 1986). Bireyler içinde bulundukları duruma yönelik, yapabileceklerine dair inançları arttıkça daha fazla motive olurlar ve zorluklarla baş etmede daha etkili olabilirler (Bandura, 1983). Psikolojik danışman özyeterliği ise psikolojik danışmanın sahip olduğu becerileri başarılı bir şekilde kullanabilmesi ve uygulayabilmesi doğrultusundaki yeterliğine dair inancıdır (Bakioğlu,2017). Psikolojik danışma sürecinin sağlıklı ve başarılı bir şekilde işlemesinde psikolojik danışmanların yapabileceklerine dair inançları önemli bir bileşendir (Asarlı, 2012). Örneğin, özyeterlik düzeyi yüksek olan psikolojik danışmanların, psikolojik danışmada daha az stres yaşadıkları, danışanları tanımaya daha istekli oldukları ve psikolojik danışma becerilerini uygulamaya daha hazır oldukları görülmüştür (Lannin, Gyull, Cornish, Vogel ve Madon, 2018). Aynı zamanda kendini izleme (değerlendirme) becerisi yüksek olan psikolojik danışmalar psikolojik danışma becerilerini daha etkili ve verimli öğrenebilmektedirler (Crews vd., 2005). Bunlara benzer olarak ise özyeterlik düzeyi düşük olan psikolojik danışmanlar psikolojik danışma oturumu öncesi stres yaşama potansiyeline sahiptirler (Lannin vd., 2018).

Özyeterlik düzeyinin düşük olmasına bağlı olarak oluşan bütün bu tepkiler, stresli geçen bir psikolojik danışma oturumundan sonra olumsuzlukla ya da yetersizlikle sonuçlanırsa psikolojik danışmanın özyeterlik düzeyinin düşmesine neden olabilmektedir. Psikolojik danışmanların özyeterlik düzeylerinin, onların psikolojik danışma performanslarını yüksek düzeyde etkilemesi sebebiyle özyeterlik alanında çalışmalar yapılması, psikolojik danışmanların özyeterliğini yükseltmeye yönelik uygulamaların yapılması oldukça önemlidir. Rønnestad ve Skovholt (2003), son zamanlarda psikolojik danışmanların eğitim ve gelişimlerine olan ilginin artması ile psikolojik danışmanların yeterlik düzeylerine yönelen araştırmaların da arttığını belirtmişlerdir. Bu nedenle bu araştırmanın 
ülkemizdeki psikolojik danışman adaylarının; psikolojik danışma becerileri düzeylerinin incelenmesi ve psikolojik danışma becerilerini etkileyen faktörlerin belirlenmesi açısından önemli olduğu düşünülmektedir.

Psikolojik danışma becerileri ve psikolojik danışman özyeterliği ile ilgili yapılan son araştırmalar psikolojik danışmanların; yansıtma becerileri, cesaretlendirme, dinleme, kendini açma, asgari düzeyde teşvik, yüzleştirme ve soru sorma becerilerini iyi düzeyde kullandıklarını göstermektedir (Atıcı ve Ulusoy, 2010; Şahin, Togay ve Atıcı, 2019). Bunun yanında psikolojik danışmanların en çok istismar vakaları ve psikolojik danışmanların yetkinlik sınırlarını aşan konularda zorlandıkları alan yazında karşılaşılan sonuçlar arasındadır (Çelik, 2019; Kaya ve Yıldıım, 2017).

$\mathrm{Bu}$ araştırmanın amacı psikolojik danışman adaylarının psikolojik danışma becerileri ve psikolojik danışman özyeterliğine yönelik algılarının ortaya koymaktır. Araştırmadan elde edilen bulguların, psikolojik danışman eğitimi, psikolojik danışma becerileri eğitimi, psikolojik danışman özyeterliği alan yazınına katkı sağlaması ve psikolojik danışman adaylarının eğitiminde kullanılacak olan programlara ışık tutması beklenmektedir. Bu amacı gerçekleştirebilmek için aşağıdaki sorulara yanıt aranmıştır:

1.Psikolojik danışman adaylarının mikro yardım becerilerini etkili kullanma ile ilgili algıları nasıldır?

2. Psikolojik danışman adaylarının kullanmada güçlük çektikleri mikro yardım becerileri ile ilgili algıları nasıldır?

3. Psikolojik danışman adaylarının geliştirmek istedikleri mikro yardım becerileri ile ilgili algıları nasıldır?

4.Psikolojik danışman adaylarının etkili çalıştıkları danışanlara yönelik algıları nasıldır?

5.Psikolojik danışman adaylarının çalışmakta güçlük çektikleri danışanlara yönelik algıları nasıldır?

\section{Yöntem}

Çalışma araştırmanın amacı doğrultusunda nitel araştırma yöntemlerinden biri olan durum çalışması modeline uygun olarak gerçekleştirilmiştir. Nitel araştırma bir olayın, olgunun ya da durumun derinlemesine incelenmesine olanak sağlayan bir yöntemdir (Büyüköztürk, Kıllı̧-Çakmak, Akgün, Karadeniz ve Demirel, 2020). Durum çalışması yapısı itibariyle neden ve nasıl sorularına cevap ararken bireyi ya da bir grubu anlayabilme, tanılayabilme ve tahmin etmeyi içerir (Akar, 2019).

\section{Çalışma Grubu}

Nitel araştırmalarda amaç araştırmaya katılan bireylerin konu ile ilgili deneyim ve anlayışlarının belirlenmesidir (Gürbüz ve Şahin, 2018). Araştırmanın çalışma grubu maksimum çeşitlilik yöntemi ile seçilen 2020-2021 eğitim öğretim yılında İzmir, Manisa, Düzce, Sakarya ve Aydın illerinde Psikolojik Danışmanlık ve Rehberlik Bölümünde eğitim görmekte olan 93'ü (\%72.1) kadın ve 36'sı (\%27.9) erkek toplam 129 son sınıf psikolojik danışman adayından oluşmaktadır. Araştırmaya ilişkin verilerin sunumunda katılımcılar "K" olarak kodlanmıştır.

\section{Veri Toplama Araçları}

Yarı Yapılandırıımış Görüşme Formu: Araştırmada psikolojik danışman adaylarının psikolojik danışma becerileri ve özyeterlikleri konusundaki algıları hakkında bilgi sahibi olabilmek amacıyla yarı yapılandırılmış görüşme tekniğine uygun bir şekilde araştırmacı tarafınca geliştirilmiş olan yarı yapılandırılmış görüşme formundan yararlanılmıştır. Yarı yapılandırılmış görüşme formu 5 açık uçlu sorudan oluşmaktadır. Sorular hazırlanırken ilgili alan yazın taranmış ve soru havuzu oluşturulmuştur. 
Psikolojik danışma alanındaki en az doktora düzeyinde 3 uzmanın görüşüne başvurularak geribildirim alınmış ve sorulara son şekli verilmiştir. Yarı yapılandırılmış görüşme formuna ait sorular aşağıdaki şekildedir:

1. Mikro yardım becerileri arasından hangi beceri/becerileri daha etkili kullanıyorsunuz?

2. Mikro yardım becerileri arasından hangi beceri/becerileri kullanmakta güçlük çekiyorsunuz?

3. Mikro yardım becerilerinden arasından hangi beceri/becerileri daha fazla geliştirmek istersiniz?

4. Kendi kişisel özelliklerinizi düşündüğünüz zaman hangi danışanlarla daha etkili çalışıyorsunuz?

5. Kendi kişisel özelliklerinizi düşündüğünüz zaman hangi danışanlarla çalışmakta güçlük çekiyorsunuz?

Kişisel Bilgi Formu: Araştırmaya katılan psikolojik danışman adaylarına ait demografik değişkenleri belirlemek adına araştırmacı tarafından kişisel bilgi formu geliştirilmiştir. Bu formda cinsiyet ve genel ağırlıklı not ortalaması (GANO) bilgileri yer almıştır.

\section{İşlem Yolu}

Belirlenen yükseköğretim kurumlarında 2020-2021 yılında eğitim görmekte olan Psikolojik Danışmanlık ve Rehberlik bölümü 4. sınıf öğrencilerine araştırmacı tarafından araştırmada kullanılan yarı yapılandırılmış görüşme formu ve kişisel bilgi formu Google Anket formunda online olarak ulaştırılmıştır. Nitel verilerin alınmasında herhangi bir ses kaydı veya görüşme kaydı tekniği kullanılmamıştır. Online formda araştırmanın amacına, araştırmacıya ilişkin bilgiler ve elde edilen bilgilerin araştırmacı haricinde kimselerle paylaşılmayacağı ile ilgili gizlilik bilgileri katılımcılarla paylaşılmıştır.

\section{Verilerin Analizi}

Verilerin çözümlenmesinde içerik analizi yöntemi kullanılmıştır. İçerik analizi yönteminde kavram, düşünce ve konuları açık bir şekilde ortaya koyabilmek adına katılımcılara ait alıntılara yer verilebilir (Yıldııım ve Şimşek, 2016). Veriler incelendikten sonra hangi konu başıkları altında toplandığı belirlenmiştir ve ardından analiz işlemi tamamlanarak alt temalar ve kodlar oluşturulmuştur. Tezden üretilmiş olan bu çalışmada veriler tez danışmanı ve araştırmacı tarafından ayrı ayrı kodlanmıştır. Bu kodlamaların ardından elde edilen kodların birbirlerine benzerlik oranı araştırmanın güvenirliğini ortaya koyar ve oldukça önemlidir. Bu nedenle tez danışmanı ve araştırmacı arasında uzlaşı sağlanıp benzerlik oranı belirlenmiştir. Nitel araştırmalardaki bu benzerlik oranı Miles- Huberman modelinde iç tutarlılık olarak da adlandırılır ve araştırmanın kodlayıcıları arasındaki fikir birliğini ortaya koyar. Benzerlik oranı $\Delta=C \div(C+\partial) \times 100$ formülasyonu kullanılarak hesaplanabilir. Formülasyona göre $\Delta$ : Güvenirlik katsayısını, $C$ : Üstünde fikir birliği sağlanmış olan konu/terim sayısını, d: Üstünde fikir birliği sağlanmayan konu/terim sayısını ifade etmektedir ve bu benzerlik oranının en az \%80 olması beklenmektedir (Miles ve Huberman; 1994 akt. Baltacı, 1994). Nitel araştırmaların bir diğer önemli noktası ise iç ve dış geçerliktir. İç geçerlik araştırmayı gerçekleştiren kişinin belirlediği temaların, kodların ve özelliklerin gerçeği yansıtma derecesine bağlıdır (Büyüköztürk vd., 2020). Dış geçerlik ise örneklemin evrene genellenebilirlik durumu ile ilgilidir. Araştırmanın nitel bölümü için gerekli güvenirlik hesaplamaları yapılmıştır ve .87 sonucuna ulaşıımıştır. Bulgular kısmında verilerden elde edilmiş olan doğrudan alıntılara yer verilmiştir. Doğrudan alıntıların kullanılma amacı araştırmanın iç geçerliğini artırmaktır. Araştırma sonucunda elde edilen bulgularda katılımcıların kimlikleri (K1, K2...) gizli tutulmuştur. 


\section{Bulgular}

Araştırmadan elde edilen bulgular, araştırma soruları esas alınarak aşağıda belirtilmiştir.

\section{Birinci ana tema: Psikolojik danışman adaylarının etkili kullandıkları mikro yardım becerileri}

Katılımcılara, psikolojik danışman adaylarının mikro yardım becerilerini etkili kullanma ile ilgili algılarının nasıl olduğunu belirlemek amacıyla sorulan soruya verdikleri cevaplar değerlendirilmiştir. Bu sorudan elde edilen verilere göre en fazla hem temel düzeyde hem de ileri düzeyde yardım becerileri içerisinde yer alan içerik yansıtma, duygu yansıtma, soru sorma, dinleme, asgari düzeyde teşvik, özetleme, odaklanma/dikkati verme, konuşmaya açık davet, kendini açma, empati, yorumlama, somutlaştırma, yüzleştirme, sessizlik, geri bildirim verme, kişiselleştirme kodlarının olduğu belirlenmiştir. Aşağıda katılımcıların vermiş oldukları yanıtlardan bazıları doğrudan alıntılanarak verilmiştir.

"içerik ve duygu yansıtması iyi olduğum bir beceridir. Zaten en sık kullandığımız becerilerden bunlar. Danışanın söylediklerini başka cümlelerle ona geri aktarmada ve duyguları anlama konusunda iyi olduğumu düşünüyorum" (K32)

"Duyguları yansıtırken daha iyiyim sanırım çok zorluk çekmiyorum psikolojik danışma esnasında. Danışan anlatırken ya da o anki duruşundan falan anlayabiliyorum neler hissettiğini. Bence ağırlıklı olarak ipuçlarını ister istemez danışan veriyor zaten" (K128)

"Duygu ve içerik yansıtma, soru sorma, dinleme, kendini açma, geri bildirim verme, yorumlama bana kolay gelenler diğerlerinde biraz daha dikkatli olmak gerekiyor. Bu saydıklarım da mesela danışanı iyi dinledikten sonra rahatııla halledilebilen şeyler" (K35)

"Kendini açma bunlardan en rahat olduğum sanrım çünkü dikkat etmem gereken çok fazla bir şey yok. Eğer benzer bir şey yaşamışsam kendimden örnek verebiliyorum. Çok fazla detaya girmiyorum sadece hani psikolojik danışmaya gelen benmişim gibi olmasın yeterli" (K116)

İkinci ana tema: Psikolojik danışman adaylarının kullanmakta güçlük yaşadıkları mikro yardım becerileri

Katılımcılara, psikolojik danışman adaylarının kullanmada güçlük çektikleri mikro yardım becerileri ile ilgili algılarının nasıl olduğunu belirlemek amacıyla sorulan soruya verdikleri cevaplar değerlendirilmiştir. Bu sorudan elde edilen verilere göre en fazla hem temel düzeyde hem de ileri düzeyde yardım becerileri içerisinde yer alan duygu yansıtma, içerik yansıtma, soru sorma, özetleme, odaklanma/dikkati verme, asgari düzeyde teşvik, dinleme, konuşmaya açık davet, yüzleştirme, sessizlik, yorumlama, kendini açma, kişiselleştirme, saydamlık ve geri bildirim verme kodlarının olduğu belirlenmiştir. Aşağıda katılımcıların vermiş oldukları yanıtlardan bazıları doğrudan alıntılanarak verilmiştir.

"Duygu yansıtmada zorlanabiliyorum. Danışanın o anki durumunu yani gördüğüm duyguları söylediğimde bazen aslında tam olarak değil, öyle değil vs tepkileri alabiliyorum. E benim gördügümm şey doğru değilse ki aslında doğru bence ne yapacağımı bilemez halde kalıyorum bu sefer" (K122)

"içerik yansıtma zor ya. O kadar çok şey söylüyor ki danışan bazen hani hepsi sanki önemli gibi geliyor. Onca şey arasından asıl noktaya vurgu yapmak gerekiyor bazen de sadece asıl konunun etrafında dolanıyoruz. Gereksiz şeyleri yansıtmak da sadece vakit öldürmek yani" (K58)

"Duygu yansıtma ve kendini açma ikisi en çok dikkatli olunması gereken beceriler benim için. Neyden bahsedeceğimi bilemiyorum bazen. Kendimi açacağım diyelim hangi kısmını danışana söyleyeceğim hangi kısmını danışana söylemeyeceğim kafamda soru işaretleri beliriyor birden" (K59) 
"Sessizliğe yer verme. Çok rahatsız edici oluyor. Danışan suskunsa bir de o psikolojik danışma nasıl bitecek diye düşünüyorum. Danışan o sessizlikte konuşacak mı konuşmayacak mı konuşmazsa ben ne yaparım ya da ne söylemem gerekir? Bu sırada bir de danışanın son söylediğini unutursam..." (K72)

\section{Üçüncü ana tema: Psikolojik danışman adaylarınım geliştirmek istedikleri mikro beceriler}

Katılımcılara, psikolojik danışman adaylarının geliştirmek istedikleri mikro yardım becerileri ile ilgili algılarının nasıl olduğunu belirlemek amacıyla sorulan soruya verdikleri cevaplar değerlendirilmiştir. Bu sorudan elde edilen verilere göre en fazla hem temel düzeyde hem de ileri düzeyde yardım becerileri içerisinde yer alan duygu yansıtma, içerik yansıtma, soru sorma, özetleme, odaklanma/dikkati verme, konuşmaya açık davet, asgari düzeyde teşvik, dinleme, yüzleştirme, yorumlama, sessizlik, kendini açma, empati, kişiselleştirme, saydamlık, bağlama olarak belirlenmiştir. Aşağıda katılımcıların vermiş oldukları yanıtlardan bazıları doğrudan alıntılanarak verilmiştir.

"Duygu yansıtma ve duyguları tanıma noktasında kendimi geliştirmek isterim. Çok fazla emin olamıyorum bazen. Evet, duyguyu görüyorum ama karşılık olarak farklı bir tepki gelebiliyor. Belki de duyguları görmenin yanı sıra nasıl ifade edebileceğimi bilsem ya da öğrensem daha iyi olabilir" (K125)

"Soru sorma becerimin eksik olduğuna inanıyorum. Bunu geliştirmek isterim. Psikolojik danışmanın ilerlemesini sağlayan ana noktalardan biri bence soru sorabilmek ve bazen danışan bir şeyler söyledikten aklıma soru gelmediği oluyor" (K32)

"Duygu yansıtma, yüzleștirme, empatik tepki becerilerini geliştirmek beni psikolojik danıșma yaparken rahat etmem açısından daha iyi yerlere getirir. Biraz daha moda mod kalıyor bu tepkilerim genelde. Daha çok formülden ilerliyor gibiyim deşifrelere baktığımda" (K123)

"Duygu yansıtma, yorumlama, özetlemeyi geliştirsem iyi olur. Aslında çok basit gibi dursalar da daha etkili hale getirmek isterim. Özellikle yorumlama, çünkü diğerlerinde neyi hangi sırada nasıl yapacağımız biraz daha belli sanki” (K92)

\section{Dördüncü ana tema: Psikolojik danışman adaylarının etkili çalışabildikleri danışanlar}

Katılımcılara, psikolojik danışman adaylarının etkili çalıştıkları danışanlara yönelik algılarının nasıl olduğunu belirlemek amacıyla sorulan soruya verdikleri cevaplar değerlendirilmiştir. Bu sorudan elde edilen verilere göre üç alt tema belirlenmiştir. Bu temalar; danışanların kişilik özellikleri, danışanların yaşadıkları problemler ve danışanların gelişim dönemim özellikleridir.

\section{Danışanların kişilik özellikleri}

Bu alt temadan en fazla elde edilen kodlar sırasıyla; dışadönük/kendini açan/konuşkan, değişime istekli ve işbirlikçi, yumuşak başlı, uyumlu ve sakin, kötümser, kararlı, duygusal, içe dönük, mantıklı danışanlar), kendini ifade etme düzeyi ve farkındalık düzeyi, benlik algısı olumlu danışanlar, nevrotik, psikolojik danışmana benzer kültürel bir yapıdan gelenler, direnç göstermeyen, sorumluluk sahibi danışanlar olarak belirlenmiştir. Aşağıda katılımcıların vermiş oldukları yanıtlardan bazıları doğrudan alıntılanarak verilmiştir.

"Kendilerini anlayabilen, ifade edebilen işbirliğine yatkın danışanlar ile çalışmak daha rahat. Tek taraflı çabalıyormuşum ya da ne yapıyorum ben hissinden uzaklaşıp tam bir ortam sağlayabilirim." (K101)

"Kendini ifade edebilen böyle hani konuşurken biraz daha akıcı olan danışanlarla rahat çalışabilirim. Aslında öyle demek istemedim, yok yani tam olarak o değil gibi ifadelerin olması bir süre sonra benim de dikkatimi dağıtıyor." (K112) 
"Kendi hakkında düşünmeyi, düşüncelerini dile getirmeyi seven işbirliğine açık danışanlarla rahat edeceğimi düşünüyorum. Çünkü bir noktada artık kendini değiştirmesi gerekiyor ya da bunu istemesi lazım." (K89)

\section{Danışanların yaşadıkları problemler}

Bu alt temadan elde edilen kodlar sırasıyla; kaygı sorunu olan danışanlar, psikolojik durumu klinik olmayan danışanlar, bitirilmemiş işleri olan danışanlar, okulla ilgili sorunları olan danışanlar, beceri eğitimi isteyen danışanlar, güven sorunu yaşayan danışanlar, duyguları ile baş etmede zorluk yaşayan danışanlar, mesleki rehberlik, özgüven sorunu yaşayan danışanlar, ailevi problem olan danışanlar, travmatik yaşantıya sahip danışanlar olarak belirlenmiştir. Aşağıda katılımcıların vermiş oldukları yanıtlardan bazıları doğrudan alıntılanarak verilmiştir.

"Orta derecede kaygılı, şemalarıla problemi olan ve bilişsel çarpıtmaları olan danışanlarla daha rahat çalışabilirim derslerde olsun kitaplarda olsun kendi ilgim de bu yönde. Bu konuda kitaplar okuyorum, notlar alıyorum o yüzden kendimi daha güvende hissediyorum bildiğim bir alanda" (K13)

\section{Danışanların gelişim dönemi özellikleri}

Bu alt temada katılımcıların, daha çok rahatlıkla çalışabildikleri danışanların gelişim dönemleri sırasıyla; ergenlik, çocukluk, hem ergenlik hem yetişkinlik, yetişkinlik, hem çocukluk hem ergenlik olarak belirlenmiştir. Aşağıda katılımcıların vermiş oldukları yanıtlardan bazıları doğrudan alıntılanarak verilmiştir.

"Ergen danışanlarla daha rahat çalışıyorum ya da çalışması biraz daha kolay geliyor diyebilirim. Onlarla çok rahat empati kurabiliyorum çünkü ve bence rahat rahat da anlayabiliyorum, konuşurken psikolojik danışma esnasında da hissedebiliyorum bunu Danışanlar da bunu anladığı için daha verimli oluyor bence." (K12)

\section{Beşinci ana tema: Psikolojik danışman adaylarının çalışmakta güçlük yaşadıkları danışanlar}

Katılımcılara, psikolojik danışman adaylarının çalışmakta güçlük çektikleri danışanlara yönelik algılarının nasıl olduğunu belirlemek amacıyla sorulan soruya verdikleri cevaplar değerlendirilmiştir. Bu sorudan elde edilen verilere göre üç alt tema belirlenmiştir. Bu temalar; danışanların kişilik özellikleri, danışanların yaşadıkları problemler ve danışanların gelişim dönemim özellikleridir.

\section{Danışanların kişilik özellikleri}

Bu alt temadan elde edilen kodlar sırasıyla; içedönük/konuşmayan/ kendini açmayan, değişime isteksiz, isyankar, sorgulayıcı, inatçı, dünya görüşü farklı olanlar, sorumsuz, manipülatif, konuşkan, çelişkili, duygusal/melankolik, umursamaz, sabırsız, farkındalığı düşük, sabit fikirli, uyumsuz/kaba, mükemmeliyetçi, duygularını tanımayan, sinirli, karamsar, şikayetçi olarak belirlenmiştir. Aşağıda katılımcıların vermiş oldukları yanıtlardan bazıları doğrudan alıntılanarak verilmiştir.

"Sessiz, konuşmaya istekli olmayan danışanlarla. Ben de tıkanıyorum o zaman.Bu sefer psikolojik danışma ilerlemiyor, benim kaygı seviyem yükseliyor bir diğer yandan saate bakıyorum vakit geçmiyor. Çok zor oluyor. "(K19)

"Değişime direnen ve umutsuz vakalar ile çalışmak.. Ne olursa olsun böyle sürekli kendilerini aşağı çekiyorlar sanki. E durum bu olunca bir süre sonra benim de modum düşüyor. Bakış açıları çok karanlık olan, sonuna kadar artık o acıyı çekse de bırakamayanlar çalışması en zor kişiler bence" (K98) 


\section{Danışanların yaşadıkları problemler}

Bu alt temadan elde edilen kodlar sırasıyla; kaygı sorunu olan danışanlar, istismar veya tacize uğrayan danışan, intihara meyilli, istismar/taciz/adam öldürme suçu olan danışan, depresyonda olan, yas danışmanlığı, psikotik, şiddet görmüş danışan, özgüven sorunu olan danışanlar, şiddet uygulayan danışan, yoğun desteğe ihtiyaç duyan danışan, karmaşık sorunları olan danışan, romantik ilişkiler, bilişsel ve ruhani sorunlar, psikolojik danışmanın baş etmekte zorlandığı sorunlara sahip danışanlar, obsesif, sosyal fobisi olan, öfkeli, geçmişe takılı kalan, benlik saygısı düşük olarak belirlenmiştir. Aşağıda katılımcıların vermiş oldukları yanıtlardan bazıları doğrudan alıntılanarak verilmiştir.

"istismara uğramış bir bireyle çalışmak. Onların yaşadıkları bana çok zor geliyor. Ne yapacağımı bilemem diye düşünüyorum. Karşımda daha önce uğramadığım, yaşamadığım bir olay beliriyor ve bu öyle kolay bir şey de değil. Oldukça travmatik" (K14)

"intihar eğilimi olan danışanlarla çalışmada zorluk yaşayabilirim bu konuda işin resmi boyutu da var çünkü ilgili yerlere haber vermek gibi. Bir de ben hani daha güven sağlayamamışım direkt resmi yerlere haber versem bu sefer danışanı kaybederim gibi düşünceler var kafamda" (K99)

\section{Danışanların gelişim dönemi özellikleri}

Bu temadan elde edilen kodlar sırasıyla; yetişkinlik, çocukluk, yaşlılık, ergenlik olarak belirlenmiştir. Aşağıda katılımcıların vermiş oldukları yanıtlardan bazıları doğrudan alıntılanarak verilmiştir.

"Yetişkinler ile çalışmakta zorlanırım biraz daha kapalılar sanki her türlü düşünceye. Mesela küçük çocuklar daha çok deneyimleyerek öğreniyorlar ya da bir şeyleri deniyorlar. Yetişkinlerde bu çok zor" (K31)

"Kalıplaşmış yapıları olduğu için ve zaman zaman değişime direnç gösterebildikleri için yaşlı danışanlarla çalışmak beni zorlayabilir. Yaşlı danışanlar evet belki ağırlıklı olarak konuşkanlar ama sizin yaşınız onunkinden küçük olduğu için bazen de konu deneyime ve daha farklı yerlere gittiği için zorluk çıkabiliyor" (K12)

\section{Tartışma, Sonuç ve Öneriler}

Bu araştırma, psikolojik danışman adaylarının psikolojik danışma becerileri ve özyeterlikleri konusunda algılarını derinlemesine incelemek amacıyla yapılmıştır. Görüşmenin ilk sorusu olan psikolojik danışman adaylarının mikro yardım becerilerinden hangilerini daha etkili kullandıklarına ilişkin katılımcıların verdikleri yanıtlar incelendiğinde içerik yansıtma, duygu yansıtma, soru sorma, dinleme, asgari düzeyde teşvik, özetleme, odaklanma/dikkati verme, konuşmaya açık davet, kendini açma, empati, yorumlama, somutlaştırma, yüzleştirme, sessizlik, geri bildirim verme, kişiselleştirme becerilerini daha etkili kullandıkları sonucuna ulaşıımıştır. Araştırmadan elde edilen bu sonuç Atıcı ve Ulusoy'un (2010) psikolojik danışman adaylarının yansıtma becerileri, cesaretlendirme, dinleme, kendini açma, yüzleştirme ve soru sorma becerilerini iyi düzeyde kullandıkları sonucu ile paralellik göstermektedir. Aynı zamanda benzer sonuçlara ulaşmış olan Şahin vd.'nin (2009) psikolojik danışmanların sıklıkla; içerik ve duygu yansıtma, cesaretlendirme, yapılandırma, asgari düzeyde teşvik, yüzleştirme ve kendini açma becerilerini kullandıkları sonucunu desteklemektedir. Xiangyi'nin (2009) sonuçlarına göre ise Çinli psikoterapistler psikolojik danışmada teknik becerilere ve psikolojik danışma becerilerine odaklanmaktan çok danışanlarla ilişki kurmaya odaklanırlar. Ülkemizde ise psikolojik danışma becerileri eğitiminde terapötik koşullara ve temel düzey psikolojik danışma becerilerine ağılık verilmektedir (Aladağ, 2013). Bu nedenle psikolojik danışman adaylarının temel düzey becerileri etkili kullandıklarını belirtmelerinin aldıkları eğitim ile tutarlı olduğu söylenebilir. 
Görüşmenin ikinci sorusu olan psikolojik danışman adaylarının mikro yardım becerilerinden hangilerini kullanmakta güçlük çektiklerine ilişkin katılımcıların verdikleri yanıtlar incelendiğinde duygu yansıtma, içerik yansıtma, soru sorma, özetleme, odaklanma/dikkati verme, asgari düzeyde teşvik, dinleme, konuşmaya açık davet, yüzleştirme, sessizlik, yorumlama, kendini açma, kişiselleştirme, saydamlık ve geri bildirim verme becerilerini kullanmada güçlük yaşadıkları sonucuna ulaşıımıştır. Aladağ, Yaka ve Koç (2014) yaptıkları araştırmada psikolojik danışman adaylarının en çok zorlandıkları temel düzey becerilerin; sözel takip, soru sorma ve duygu yansıtma olduğu sonucuna ulaşmışlardır. Psikolojik danışmanların kullanmakta güçlük çektikleri becerilerden yansıtma becerileri birçok psikolojik danışma becerisinin temeli sayılabilecek, etkili terapötik ilişki ve iletişimin önemli bir unsurudur (Meydan, 2015). Psikolojik danışman adaylarının psikolojik danışma becerilerinde yaşadıkları eksiklikler ve psikolojik danışma becerilerini nasıl kullanacağını bilememeleri psikolojik danışmanda fizyolojik tepkilerle birlikte kaygı yaratır (Kozan, 2018). Psikolojik danışma becerileri kullanımında oluşan bu kaygı psikolojik danışman adayının/psikolojik danışmanın özyeterlik düzeyini olumsuz etkileyebilir. Nitekim Al-Darmaki (2004) psikolojik danışmanların özyeterlik düzeyleri arttıkça psikolojik danışma yapmaya ilişkin kaygılarının azaldığını belirtmiştir. Friedlander, Keller, Peca-Baker ve Olk (1986) da psikolojik danışman özyeterlik düzeyi ile psikolojik danışmanın anksiyetesinin ters orantılı olduğunu ortaya koymuştur.

Görüşmenin üçüncü sorusu olan psikolojik danışman adaylarının geliştirmek istedikleri mikro yardım becerilerine ilişkin katılımcıların verdikleri yanıtlar incelendiğinde duygu yansıtma, içerik yansıtma, soru sorma, özetleme, odaklanma/dikkati verme, konuşmaya açık davet, asgari düzeyde teşvik, dinleme, yüzleştirme, yorumlama, sessizlik, kendini açma, empati, kişiselleştirme, saydamlık, bağlama becerilerini geliştirmek istedikleri sonucuna ulaşılmıştır. Araştırmanın diğer sonuçları ile karşılaştırıldığında psikolojik danışman adaylarının kullanmakta güçlük çektikleri psikolojik danışma becerileri geliştirmek istedikleri söylenebilir.

Görüşmenin dördüncü sorusu olan psikolojik danışman adaylarının kendi kişisel özelliklerini düşündüklerinde hangi danışanlarla daha etkili çalıştıklarına ilişkin katılımcıların verdikleri yanıtlar incelendiğinde danışanın kişilik özellikleri kapsamında dışadönük/kendini açan/konuşkan, değişime istekli ve işbirlikçi, yumuşak başlı, uyumlu ve sakin, kötümser, kararlı, duygusal, içe dönük, mantıklı danışanlar), kendini ifade etme düzeyi ve farkındalık düzeyi, benlik algısı olumlu danışanlar, nevrotik, psikolojik danışmana benzer kültürel bir yapıdan gelenler, direnç göstermeyen, sorumluluk sahibi danışanlar ile etkili çalıştıkları sonucuna ulaşılmıştır. Psikolojik danışman adaylarının etkili çalıştıkları bir diğer konu problem alanı kapsamında değerlendirilmiştir. Psikolojik danışman adaylarının kaygı sorunu olan danışanlar, psikolojik durumu klinik olmayan danışanlar, bitirilmemiş işleri olan danışanlar, okulla ilgili sorunları olan danışanlar, beceri eğitimi isteyen danışanlar, güven sorunu yaşayan danışanlar, duyguları ile baş etmede zorluk yaşayan danışanlar, mesleki rehberlik, özgüven sorunu yaşayan danışanlar, ailevi problem olan danışanlar, travmatik yaşantıya sahip danışanlar ile daha etkili çalışıkları sonucuna ulaşıımıştır. Bir diğer değerlendirme alanı ise danışanın gelişim dönemidir. Psikolojik danışman adayları ergenlik, çocukluk, hem ergenlik hem yetişkinlik, yetişkinlik hem çocukluk hem ergenlik dönemindeki danışanlar ile etkili çalışabilmektedirler. Bu bağlamda psikolojik danışmanlık eğitiminde seçmeli dersler kapsamında psikolojik danışman adaylarının çalışma alanlarında kendilerini tanımalarına olanak sağlanabilir.

Kottler (2010), psikolojik danışmanların her zaman iletişim becerileri yüksek, yardım almaya istekli ve farkındalık düzeyi yüksek danışanlarla çalışmak istediklerini belirterek bu araştırma bulgularını desteklemiştir. Psikolojik danışmanlar, psikolojik danışma sürecinde daha kolay yol alınabiliyor olması, daha sabırlı ve psikolojik danışmana minnettar olan danışanlar olması nedeniyle dışadönük danışanları tercih ederler. Aynı zamanda psikolojik danışmada yol alması daha kolay olarak değerlendirilebilecek uyumlu, direnç göstermeyen danışan özelliklerinin sıralanması da Kottler'in (2010) ifadesini desteklemektedir. Problem alanı kapsamında psikolojik danışmanların etkili 
çalıştıkları ve çalışmakta zorlandıkları konularda en çok bahsedilen kaygı sorunu olan danışanlar olmuştur. Kaygı, alt türleri ile birlikte toplumdaki bireylerin her kesiminde en çok karşılaşılan bozukluklardan biridir (Austin ve Sciarra, 2015). Bu sebeple psikolojik danışmaların bu problem alanı konusunda etkili görmeleri ya da çalışmakta güçlük çekiyor olmaları olağan olarak yorumlanabilir.

Görüşmenin beşinci sorusu olan psikolojik danışman adaylarının kendi kişisel özelliklerini düşündüklerinde hangi danışanlarla çalışmakta güçlük çektiklerine ilişkin katılımcıların verdikleri yanıtlar incelendiğinde danışanın kişilik özellikleri kapsamında içedönük/konuşmayan/ kendini açmayan, değişime isteksiz, isyankâr, sorgulayıcı, inatçı, dünya görüşü farklı olanlar, sorumsuz, manipülatif, konuşkan, çelişkili, duygusal/melankolik, umursamaz, sabırsız, farkındalığı düşük, sabit fikirli, uyumsuz/kaba, mükemmeliyetçi, duygularını tanımayan, sinirli, karamsar, şikayetçi danışanlar oldukları sonucuna ulaşımıştır. Psikolojik danışman adaylarının çalışmakta güçlük yaşadıkları bir diğer konu problem alanı kapsamında değerlendirilmiştir. Psikolojik danışman adaylarının kaygı sorunu olan danışanlar, istismar veya tacize uğrayan danışan, intihara meyilli, istismar/taciz/adam öldürme suçu olan danışan, depresyonda olan, yas danışmanlığı, psikotik, şiddet görmüş danışan, özgüven sorunu olan danışanlar, şiddet uygulayan danışan, yoğun desteğe ihtiyaç duyan danışan, karmaşık sorunları olan danışan, romantik ilişkiler, bilişsel ve ruhani sorunlar, psikolojik danışmanın baş etmekte zorlandığı sorunlara sahip danışanlar, obsesif, sosyal fobisi olan, öfkeli, geçmişe takılı kalan, benlik saygısı düşük olan danışanlar ile çalışmakta güçlük yaşadıkları sonucuna ulaşılmıştır.

Araştırma sonuçları doğrultusunda psikolojik danışman adayları içedönük/konuşmayan/ kendini açmayan danışanlar ile çalışmakta zorlandıklarını belirtmişlerdir. Bu durumun psikolojik danışman adaylarının psikolojik danışma oturumu yönetmeye ilişkin deneyimlerinin az olmasından kaynaklanıyor olduğu yorumu yapılabilir. Ayrıca kişilik gelişimi açısından psikolojik danışman kimliğini içselleştiremedikleri, farklı yaşam deneyimlerine objektif, koşulsuz, kabul edici ve empatik olmada sıkıntı yaşıyor olabilecekleri düşünülmektedir. Nitekim Johnson, Baker, Kopala, Kiselica ve Thompson (1989) psikolojik danışma uygulaması öncesi verdikleri eğitimde psikolojik danışman adaylarının eğitimin başında özyeterlik düzeylerinin düşük ve kaygı düzeylerinin yüksek olduğu sonucuna ulaşmışlardır. Psikolojik danışman adaylarının deneyimleri ve özyeterlik düzeyleri arttıkça içe dönük danışanlarla çalışmaya yönelik yargılarının değişebileceği söylenebilir. Problem alanı kapsamında psikolojik danışmanların çalışmakta güçlük çektikleri konularda en çok bahsedilen kaygı sorunu olan danışanlar olmuştur. Psikolojik danışman adayları aynı zamanda etkili çalışabildikleri danışan problem alanı olarak da kaygı sorunu olan danışanları belirtmişlerdir. Toplumda en çok karşılaşılan bozukluklardan olan kaygı ile çalışmada güçlük çekiyor olmaları olağan olarak yorumlanabilir.

Psikolojik danışmanların çalışmakta zorluk çektikleri bir diğer grup ise tehlikeli danışanlar ve riskli grup olarak adlandırabileceğimiz; istismara uğramış veya istismar suçu olan, herhangi bir suça karışmış, intihar eğilimi olan bireylerdir. Türk PDR-DER etik kurallarında (2011) "psikolojik danışmanlar, yalnızca eğitim aldıkları, yeterince gözetim altında uygulama yaparak ya da uygun yeterli profesyonel uygulamalar yürüterek yetiştirildikleri uzmanlık alanlarında hizmet verebilir, ögrretebilir ve araştırma yapabilirler" ibaresi yer almaktadır. Psikolojik danışman adaylarının yetkinlik sınırlarının farkında olup tehlikeli danışanlar ve risk grupları ile çalışırken güçlük yaşamaları ya da güçlük yaşayabilecek olmaları beklendik bir sonuç olarak değerlendirilebilir. Çelik (2019) okul psikolojik danışmanları ile yaptığı araştırmasında psikolojik danışmanların istismar vakalarıyla çalışmada pek çok yönden zorluk yaşadıklarını belirtmiştir. İstismar ile çalışmadaki zorlukların sebebi ağırıkı olarak süreç içerisinde psikolojik danışmanın yalnız kalması, aile, öğretmen ve idare ile yaşanan sorunlardır. Kaya ve Yıldırım (2017) yaptıkları araştırmada psikolojik danışmanların çözümlemede yetersiz hissettikleri konuları; ailevi problemler, madde bağımlılı̆ına ilişkin sorunlar, istismar, taciz, kişilik bozuklukları ve klinik tedavi gerektiren durumlar olarak belirtmişlerdir. TuzgölDost ve Keklik (2012) ise okullarda çalışan psikolojik danışmanlarla yaptıkları araştırmada psikolojik danışmanların kendilerini özel eğitim, klinik tedavi gerektiren durumlar, sınava ilişkin problemler, 
travma ve krize müdahale alanlarında yetersiz buldukları sonucuna ulaşmışlardır. Bu sonuçlar doğrultusunda psikolojik danışmanların/psikolojik danışman adaylarının çalışmakta güçlük çektikleri danışanların farklılaşmasının sebebi bireylerin aldıkları eğitime ilişkin farklılıklar, psikolojik danışma oturumu deneyiminin az olması ve çok fazla danışan çeşidi ile karşılamamaları olabilir. Aynı zamanda riskli ve tehlikeli gruplarla çalışırken emniyet güçleri, Aile ve Sosyal Politikalar Bakanlığı, kolluk kuvvetleri gibi birçok alanla koordineli hareket etmenin veya edecek olmanın psikolojik danışmanların özyeterlik düzeyini etkileyebileceği düşünülmektedir. Bu kapsamda psikolojik danışmanların/psikolojik danışman adaylarının etik eğitim almaları, tehlikeli danışanları ve özelliklerini öğrenmeleri, karar verme ve baş etme becerilerini geliştirmeleri önerilebilir (ikiz, 2017).

$\mathrm{Bu}$ araştırmanın bazı sınırlılıkları bulunmaktadır. Bu sınırıkların en önemlisi araştırmanın bulguları 129 öğrenciden elde edilmesidir. Ayrıca araştırmanın verileri, araştırmada kullanılmış olan yarı yapılandırılmış görüşme formu ile sınırlıdır.

Bu araştırmada Rehberlik ve Psikolojik Danışmanlık alanında eğitim görmekte olan 4.sınıf öğrencileri ile çalışılmıştır. Mezun olmuş/ çalışan psikolojik danışmanlar gibi farklı örneklem grupları ile çalışılabilir. Bu nedenle yapılacak olan çalışmalar farklı psikolojik danışma becerileri eğitim yaklaşımları kullanılarak deneysel olarak gerçekleştirilebilir. Psikolojik danışman adaylarının ve psikolojik danışmanların psikolojik danışma becerilerini geliştirmeye yönelik kültüre duyarlı bir eğitim programı geliştirilebilir. Psikolojik danışmanların kendilerinin de psikolojik danışma sürecinden geçerek farkındalıklarını artırmaları ve çalışmada zorluk yaşadıkları danışanlara yönelik psikolojik danışma becerilerini geliştirici eğitimlerden faydalanmaları önemli görülmektedir. Mevcut eğitim programlarına ek olarak psikolojik danışman adaylarına zor danışanlar ve travma psikolojik danışmanlığı konularında seçmeli ders imkanları sağlanabilir. Psikolojik danışmanların zorlu problem alanları ve danışanlarla çalışmaya yönelik sosyal beceri programları düzenlenebilir, süpervizyon desteği sağlanabilir. Psikolojik danışmanların etik karar verme becerileri geliştirilebilir. Psikolojik danışmanların farklı profillerdeki ve tehlikeli danışanlarla çalışma güçleri artırılabilir. 


\section{Kaynakça}

Aladağ, M. (2013). Rehberlik ve psikolojik danışmanlık lisans programlarında psikolojik danışma uygulaması öncesinde psikolojik danışma becerileri eğitimi: Betimsel bir inceleme. Kuram ve Uygulamada Eğitim Bilimleri, 13(1), 55-79.

Aladağ, M., Yaka, B. ve Koç, İ. (2014). Psikolojik danışma becerileri eğitimine ilişkin psikolojik danışman adaylarının görüşleri. Kuram ve Uygulamada Eğitim Bilimleri, 14(3), 859-886. doi: 10.12738/estp.2014.3.1958

Akar, H. (2019). Durum çalışması. A. Saban ve A. Ersoy (Ed.), Eğitimde nitel araştırma desenleri (s. 139-176) içinde. Ankara: Anı Yayıncılık.

Al-Darmaki, F. R. (2004). Counselor training, anxiety, and counseling self-efficacy: Implications for training psychology students from the United Arab Emirates University. Social Behavior and Personality: An International Journal, 32(5), 429-439. doi: https://doi.- org/10.2224/sbp.2004.32.5.429

Asarlı, Z. (2012). Okullarda çalışan psikolojik danışmanların okul psikolojik danışmanı öz-yeterlik düzeylerinin incelenmesi (Yayımlanmamış yüksek lisans tezi). Ege Üniversitesi, Eğitim Bilimleri Enstitüsü, İzmir.

Atıcı, M. ve Ulusoy, Y. (2010). Psikolojik danışman adaylarının grup rehberliği etkinliğini yürütürken kullandıkları psikolojik danışma becerilerinin, bu becerileri kullanmaya ilişkin yeterlik algılarının ve grup yönetimini sağlama yöntemlerinin incelenmesi. Çukurova Üniversitesi Sosyal Bilimler Enstitüsü Dergisi, 19(1), 6281.

Austin, V. L. ve Sciarra, D. T. (2015). Çocuklarda ve ergenlerde duygusal ve davranışsal bozukluklar. Ankara: Nobel Akademik Yayıncılık.

Baltacı, A. (2017). Nitel veri analizinde Miles-Huberman modeli. Ahi Evran Üniversitesi Sosyal Bilimler Enstitüsü Dergisi (AEÜSBED), 3(1), 1-15.

Bakioğlu, F. (2017). Psikolojik danışman adaylarının özyeterlikleri ile kültüre duyarlılıkları, cinsiyet rolleri ve bilinçli farkındalıkları arasındaki ilişkilerin incelenmesi (Yayımlanmamış doktora tezi). Eskişehir Anadolu Üniversitesi, Eğitim Bilimleri Enstitüsü, Eskişehir.

Büyüköztürk, Ş., Kılıç Çakmak, E., Akgün, Ö.E., Karadeniz, Ş. ve Demirel, F. (2020). Bilimsel araştırma yöntemleri (28. bs.). Ankara: Pegem Yayınları.

Bandura, A. (1983). Self-efficacy determinants of anticipated fears and calamities. Journal of Personality and Social Psychology, 45(2), 464-469. doi: 10.1037/0022-3514.45.2.464

Bandura, A. (1986). The explanatory and predictive scope of self-efficacy theory. Journal of Social and Clinical Psychology, 4(5), 359-373.

Çelik, T. H. (2019). Okul psikolojik danışmanlarının çocuk istismarı vakalarındaki deneyimleri üzerine nitel bir çalışma (Yayımlanmamış yüksek lisans tezi). Çukurova Üniversitesi, Eğitim Bilimleri Enstitüsü, Adana.

Crews, J., Smith, M. R., Smaby, M. H., Maddux, C. D., Torres- Rivera, E., Casey, J. A. ve Urbani, S. (2005). Selfmonitoring and counseling skills: skills-based versus interpersonal process recall training. Journal of Counseling and Development, 83(1), 78-85. doi: 10.1002/j.1556-6678.2005.tb00582.x

Friedlander, M. L., Keller, K. E., Peca-Baker, T. A. ve Olk, M. E. (1986). Effects of role conflict on counselor trainees' self-statements, anxiety level, and performance. Journal of Counseling Psychology, 33(1), 7377.

Gürbüz, S. ve Şahin, F. (2018). Sosyal bilimlerde araştırma yöntemleri. Ankara: Seçkin Yayıncılık.

Hackney, H. ve Cormier, S. (2008). Psikolojik danışma ilke ve teknikleri: Psikolojik yardım süreci el kitabı (T. Ergene ve S. Aydemir, Çev.). Ankara: Mentis Yayıncılık.

ikiz, F. E. (2017). Meslek etiği ve yasal konular. İstanbul: Lisans Yayıncılık.

Johnson, D., Shertzer, B., Linden, J. E. Ve Stone, S. C. (1967). The relationship of counselor candidate characteristics and counseling effectiveness. Counselor Education and Supervision, 297-304. doi: 10.1002/j.1556-6978.1967.tb00940.x

Kaya, M. ve Yıldırım, T. (2017). Liselerde çalışan psikolojik danışmanların okullarda yaşanan kriz durumlarına ilişkin algıları. Insan ve Toplum Bilimleri Araştırmaları, 6(2), 835-857.

Koban, i. (2018). Psikolojik danışmanların çok kültürlü psikolojik danışma yeterliklerinin psikolojik danışma becerilerini yordama düzeyi (Yayımlanmamış yüksek lisans tezi). Sabahattin Zaim Üniversitesi, Eğitim Bilimleri Enstitüsü, İstanbul.

Kottler, J. A. (2010). Terapist olmak üzerine. Pegasus Yayınları: İstanbul.

Lannin, D. G., Guyll, M., Cornish, M. A., Vogel, D. L. ve Madon, S. (2018). The importance of counseling selfefficacy: physiologic stress in student helpers. Journal of College Student Psychotherapy, 1-11. doi: 10.1080/87568225.2018.1424598. 
Meydan, B. (2015). Psikolojik danışman adaylarının içerik yansıtma ve duygu yansıtma becerilerine ilişkin yeterlik düzeylerinin incelenmesi. Hacettepe Üniversitesi Eğitim Fakültesi Dergisi, 30(4), 1-15.

Rønnestad, M. H. ve Skovholt, T. M. (2003). The journey of the counselor and therapist: research on Professional development. Journal of Career Development, 30(1), 5-44. doi: $10.1177 / 089484530303000102$

Şahin, İ., Togay, A. ve Atıcı, M. (2019). Psikolojik danışman adaylarının terapötik beceri ve koşullara ilişkin algıları. Journal of Human Sciences, 16(1), 56-72. doi:10.14687/jhs.v16i1.5347

Tuzgöl-Dost, M. ve Keklik, í. (2012). Alanda çalışanların gözünden psikolojik danışma ve rehberlik alanının sorunları. Mehmet Akif Ersoy Üniversitesi Eğitim Fakültesi Dergisi, 23(1), 389-407.

Türk Psikolojik Danışma ve Rehberlik Derneği. (2011). Psikolojik danışma ve rehberlik alanında çalışanlar için etik kurallar (8. bs.). Ankara: Türk PDR Derneği Yayınları

Uslu, M. (2005). Psikolojik danışmanların danışma becerilerinin geliştirilmesi (Yayımlanmamış doktora tezi). Selçuk Üniversitesi, Sosyal Bilimler Enstitüsü, Konya.

Voltan- Acar, N. (2015). Yeniden terapötik iletişim-kişiler arası ilişkiler- (tamamı bizim toplumdan örnekler). Ankara: Nobel Yayıncılık.

Xiangyi C. (2009). An exploratory study of Chinese psychotherapists' understanding and experiences of professional relationship in Mainland China (Yayımlanmamış doktora tezi). The Chinese University of Hong Kong, Department of Cultural and Religious Studies, Hong Kong.

Yaka, B. (2005). Psikolojik danışmanların temel psikolojik danışma becerilerine ilişkin yeterlik düzeylerinin bazı değişkenlere göre incelenmesi (Yayımlanmamış yüksek lisans tezi). Ege Üniversitesi, Eğitim Bilimleri Enstitüsü, İzmir.

Yıldııım, A. ve Şimşek, H. (2016). Sosyal bilimlerde nitel araştırma yöntemleri (10. bs.). Ankara: Seçkin Yayınevi. 